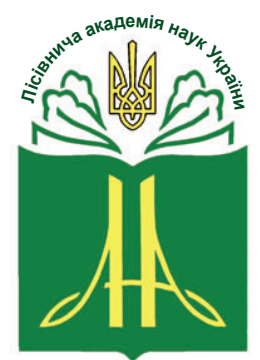

Forestry Academy of Sciences of Ukraine

Наукові праці Лісівничої академії наук України Proceedings of the Forestry Academy of Sciences of Ukraine

http://fasu.nltu.edu.ua https://doi.org/10.15421/412006

Article received 2020.01.28

Article accepted 2020.06.04
ISSN 1991-606X print

ISSN 2616-5015 online

(a) $\triangle$ Correspondence author Iryna Koval

Koval_Iryna@ukr.net

Pushkinska st., 86, Kharkiv, 61024, Ukraine.

УДК: 630.561 .24

\title{
Реакція радіального приросту Quercus robur L. на зміни клімату в Поліссі та Лісостепу
}

\author{
І. М. Коваль ${ }^{1}$
}

Досліджено стиглі та перестиглі дубові насадження в Поліссі та Лісостепу, які ростуть в умовах свіжого сугруду та свіжого груду. Встановлено кліматичні чинники, які впливають на радіальний приріст дуба звичайного (Quеrcus robur L.) в Поліссі та Лісостепу і порівняно його реакції на зміни клімату в обох природних зонах. Виявлено реперні роки максимального (1891, 1902, 1924, 1931, 1957, 1971, 1987) та мінімального (1895, 1906, 1918, 1922, 1929, 1936, 1950, 1976, 1992, 2000, 2005) радіального приросту дуба звичайного для Полісся, а також позитивні $(1971,1978,1987)$ та негативні $(1918,1922,1929,1936,1950,1976,1992,2000,2005$ реперні роки для Лісостепу. Негативні реперні роки характеризуються дефіциттом опадів, посухами вегетаційного періоду, холодними або занадто теплими зимовими та ранньовесняними періодами, а позитивні - сприятливим для росту дерев співвідношенням тепла і вологи.

Для першого періоду (1960-1988 рр.) виявлено позитивний вплив зимових та ранньовесняних температур на радіальний приріст дуба у Поліссі і Лісостепу. У другому періоді (1989-2013 рр.) відбувся протилежний сценарій - значне підвищення зимових та ранньовесняних температур призвело до зменшення радіального приросту. У другому періоді дубові насадження в Поліссі більше потерпали від теплих зим, ніж насадження в Лісостеnу. Негативний вплив посух вегетаційного періоду на приріст посилився у другому періоді для обох насаджень. Упродовж другого періоду опади суттєво втратили позитивний вплив на приріст у насадженнях як Полісся, maк $i$ Лicocmeny.

Підтверджено гіпотезу щчодо посилення чутливості реакиії радіального приросту дуба звичайного до змін клімату в Поліссі та Лісостепу.

Ключові слова: стиглі та перестиглі дубові насадження; кліматичні чинники; річні кільия; позитивні та негативні реперні роки; посухи, чутливість дуба звичайного; кореляційний аналіз, функція відгуку.

Вступ. Quercus robur L. є поширеним деревним видом в Свропі, зокрема і в Україні (Ducousso et al., 2004). Його насадження займають 26,3\% площі державного лісового фонду України. Сучасне суттєве погіршення санітарного стану і деградація лісів України внаслідок їх масового всихання в умовах глобального потепління клімату зумовлює актуальність досліджень реакції дуба звичайного як лісотвірної породи на зміни клімату.
Майже в усіх частинах Свропи кліматичні сценарії Міжурядової групи 3 питань зміни клімату (IPCC) передбачають підвищення рівня опадів взимку та зниження рівня опадів влітку, а також підвищення температури повітря (Fischer et al., 2011). Середня температура в Україні за останні десять років підвищилася на $0,3-0,6^{\circ} \mathrm{C}$ (за останні 100 років - на $\left.0,7^{\circ} \mathrm{C}\right)$, що може призвести до втрати стійкості низки деревних видів (Didukh, 2009).

Коваль Ірина Михайлівна - член-кореспондент Лісівничої академії наук України, кандидат сільськогосподарських наук, старший науковий співробітник, провідний науковий співробітник лабораторії екології лісу. Український науково-дослідний інститут лісового господарства та агролісомеліорації ім. Г. М. Висоцького, вул. Пушкінська, 86, м. Харків, 61024, Україна. Тел.: +38-057-707-80-45, +38-063-28-21-995. E-mail: Koval_Iryna@ukr.net ORCID: https://orcid.org/0000-0001-6328-1418 
Кліматичні умови є визначальним чинником росту дерев (Fritts, 1976). Стратегії адаптації, спрямовані на пом'якшення наслідків глобального потепління для лісових екосистем, таких як посилення стресової посухи (Orlowsky \& Seneviratne, 2012), є предметом гострої дискусії (Kätzel \& Höppner, 2011).

Для збереження насаджень за участю Quercus robur потрібні знання не тільки про їхній сучасний стан, але й про зміни за більш тривалий період. 3 огляду на це дедалі більшого значення набувають дендрохронологічні дослідження дуба звичайного (Melekhov, 1979; Williams, 1992; Speer, 2010; Cedro, 2007; Roibu et al., 2020; Cook, 1990).

Реакція радіального приросту дуба в Україні на зміни умов довкілля недостатньо вивчена, тому дендрохронологічні дослідження мають високу актуальність, оскільки дають змогу покращити розуміння реакції дуба звичайного на зміни клімату.

Опис об'єкту та методики досліджень. Об'єктами дослідження є стиглі та перестиглі дубові насадження в Поліссі та Лісостепу, які ростуть в умовах свіжого сугруду та свіжого груду на підзолистих і темно-сірих грунтах (рис. 1, табл. 1). Предметом дослідження є динаміка величин радіального приросту дуба звичайного у зв'язку з кліматичними змінами. Мета дослідження - виявити кліматичні чинники, які впливають на радіальний приріст дуба звичайного в Поліссі та Лісостепу і порів- няти його реакцію на зміни клімату в обох природних зонах.

Основною гіпотезою дослідження є збільшення чутливості радіального приросту дуба звичайного в умовах кліматичних змін у Полісі та Лісостепу.

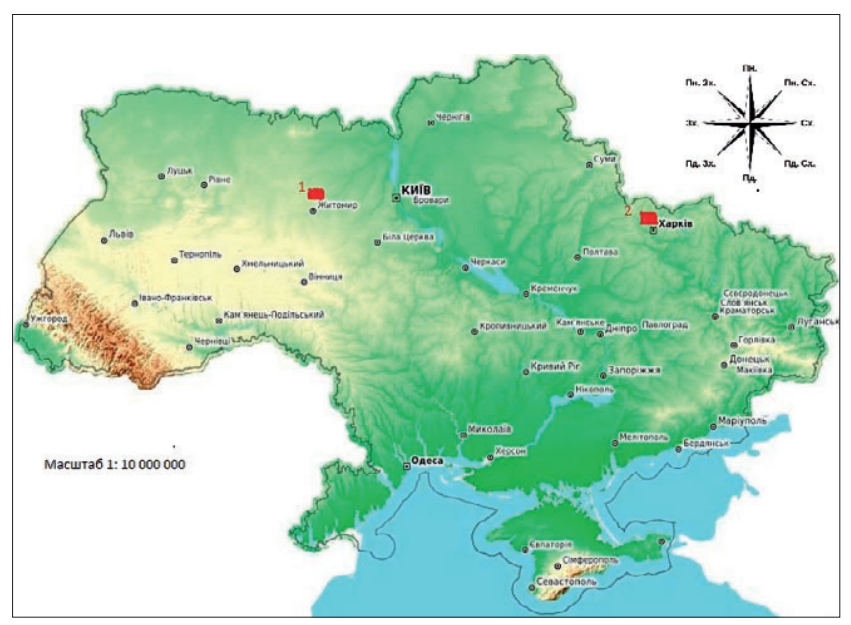

Рис. 1. Розташування місць відбору зразків у Поліссі (1) та Лісостепу (2)

У Поліссі об'єкти досліджень знаходились на території лісового фонду Пилиповецького л-ва ДП «Новоград-Волинське ДГ» (кв. 2, вид. 5), у Лісостепу - у лісовому фонді Південного л-ва Харківської лісової науково-дослідної станції (кв. 116, вид. 9).

Таблиия 1

Характеристика досліджуваних дубових насаджень

\begin{tabular}{|c|c|c|c|c|c|c|c|c|c|c|}
\hline 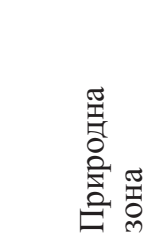 & 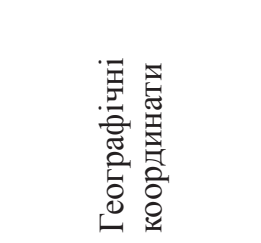 & 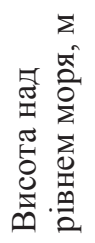 & 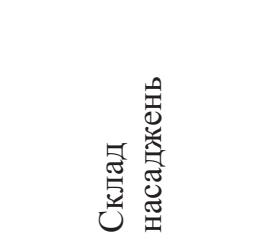 & 兊 & 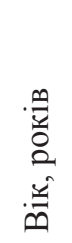 & 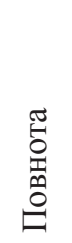 & $\begin{array}{l}\bar{\Sigma} \\
0 \\
0\end{array}$ & $\begin{array}{c}\Sigma \\
\Sigma^{0}\end{array}$ & 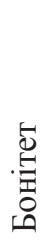 & 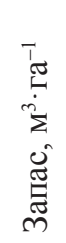 \\
\hline Полісся & $\begin{array}{l}50^{\circ} 35^{\prime} 00^{\prime \prime} \text { пн. ш. } \\
27^{\circ} 37^{\prime} 13^{\prime \prime} \text { сх. д. }\end{array}$ & 218 & $10 Д_{3}+C_{3}$, Oc, Гз & $\mathrm{C}_{2}$ & 155 & 0,5 & 44 & 28 & 2 & 260 \\
\hline Лісостеп & $\begin{array}{c}50^{\circ} 05^{\prime} 31^{\prime \prime} \text { пн. ш. } \\
36^{\circ} 17^{\prime} 40^{\prime \prime} \text { сх. д. }\end{array}$ & 202 & 10Дз & $\mathrm{D}_{2}$ & 100 & 0.6 & 40 & 25 & 2 & 270 \\
\hline
\end{tabular}

У регіоні Полісся клімат помірно-континентальний. Літо - тепле та вологе, зима - м'яка. Середня річна температура змінюється від $+6,5$ до $+7,5^{\circ} \mathrm{C}$. Середня температура січня варіює від -4.5 до $-8^{\circ} \mathrm{C}$. Температура липня становить $+18-+19^{\circ} \mathrm{C}$, середня температура липня коливається від +17 до $+19,5^{\circ} \mathrm{C}$. Річна кількість атмосферних опадів становить 550-650 мм, а найбільша їх кількість випадає в червні та липні.

У Лісостепу клімат помірно-континентальний. Середня температура липня становить від $+18^{\circ}$ до $+22^{\circ} \mathrm{C}$. Середня температура січня змінюється від -5 до $-8^{\circ} \mathrm{C}$. Опадів випадає в середньому близько 550-700 мм (Geographical encyclopedia of Ukraine, 1990).
У процесі досліджень використано дані Житомирської (50 $15^{\prime} 53^{\prime \prime}$ пн. ш., $28^{\circ} 40^{\prime} 36^{\prime \prime}$ сх. д.) та Хар-

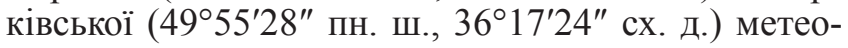
станцій, які розташовані найближче до районів досліджень.

Взаємозв'язки між радіальним приростом дуба та кліматичними чинниками розглянуто за 19601988 та 1989-2013 рр. для порівняння реакції радіального приросту до варіацій клімату за ці періоди у Поліссі і Лісостепу.

У Поліссі середньорічні температури були вищими у першому періоді, порівняно 3 другим, на $19 \%\left(8,1\right.$ та $\left.6,8^{\circ} \mathrm{C}\right)$, у березені-вересені - на $10 \%$ $\left(13,6\right.$ та $\left.12,4^{\circ} \mathrm{C}\right)$, взимку - на $41 \%\left(-2,8\right.$ та $\left.-4,7^{\circ} \mathrm{C}\right)$, a березневі температури були вищими майже вчет- 
веро $\left(1,8\right.$ та $\left.-0,5^{\circ} \mathrm{C}\right)$. Опадів у другому періоді випало на 5,8\% більше порівняно 3 першим періодом (642 та 607 мм), у березні-вересні - на 6\% (491 та 463 мм), однак у квітні-червні опадів випало на 11\% менше (192 та 173 мм). Взимку опадів випало на $8 \%$ більше (108 та 99 мм).

У Лісостепу середньорічні температури були вищими у другому періоді на $17 \%\left(8,7\right.$ та $\left.7,5^{\circ} \mathrm{C}\right)$, у березні-вересні - на $7 \%\left(17,7\right.$ та $\left.16,8^{\circ} \mathrm{C}\right)$, у квітні-червні - на 4\%, взимку - на $34 \%\left(-3,5\right.$ та $\left.-5,2^{\circ} \mathrm{C}\right)$. Найшвидше температури підвищувалися у другому періоді у березні - більше ніж в три рази і це підвищення становило у 1960-1988 pp. $-0,7^{\circ} \mathrm{C}$, у 19892013 pp. $-+1,8^{\circ} \mathrm{C}$. Опадів у другому періоді випало більше, ніж у першому за рік на 6\% (574 та 542 мм), за березень-серпень - на 10\%, за квітень-червень на 17\% (159 та 135 мм), однак впродовж зими на 10\% менше (121 та 135 мм). Також спостережено зменшення опадів упродовж липня-серпня - на $12 \%$ (107 та 123 мм).

Отже, для обох природних зон відбулося підвищення температури у другому періоді, порівняно 3 першим, на 17-19\%. Найшвидшими темпами підвищилися зимові температури (на 34-41\%) та ранновесняні (березневі температури) - майже вчетверо в Поліссі та майже втричі - в Лісостепу. Тенденції опадів подібні для обох природних зон - відбулося підвищення річної кількості опадів, але впродовж вегетаційного періоду їх випало менше у квітні-червні для Поліської зони - на 11\%, а для Лісостепової - упродовж липня-серпня та зимового періоду - на $10 \%$ менше.

У процесі досліджень використано стандартні дендрохронологічні методи (Cook et al., 1990). У 2014-2016 pр. у дубових насадженнях Полісся та Лісостепу було відібрано керни буравом Преслера зі стовбурів дерев на висоті 1,3 м по 15 зразків для кожної природної зони. Після повітряного висушування поверхня кернів була підготовлена за допомогою гострого леза, а контраст між межами річних кілець покращували за допомогою крейди. Шари річної деревини вимірювали цифровим приладом для вимірювання шарів деревини HENSON 3 точністю до 0,01 мм. Проведено перехресне датування (візуальне зіставлення всіх графіків індивідуальних хронологій), щоб встановити точну дату формування для кожного шару річної деревини (Cook et al., 1990). Результати перехресного датування перевірено за програмою COFECHA, при цьому мінімальний поріг синхронності встановлювали на рівні 90\%. Крім того, взаємозв'язок між кліматом та шириною річного кільця досліджували за допомогою аналізу функцій відгуку (Cook \& Kairiukstis, 1990). Функції відгуку обчислили за програмою RESPO $з$ програмного пакету DPL (Holmes, 1994). Методика охоплює багатофакторний регресійний аналіз, в якому середня місячна температура повітря та місячна сума опадів $є$ незалежними змінними. Програма RESPO обчислює коефіцієнти лінійної кореляції $(\mathrm{k})$ та множинної регресії $\left(\mathrm{r}^{2}\right)$. Аналіз функції відгуку застосовували для відстеження впливу кліматичних чинників на радіальний приріст за 15-місячний період (від липня попереднього року до вересня поточного року) для двох періодів - 1960-1988 та 1989-2013 роки.

Результати та обговорення. Результати статистичного аналізу річних кілець Quercus robur у Поліссі та Лісостепу свідчать про придатність деревно-кільцевих хронологій для подальшого аналізу зважаючи на те, що ці серії мають міжсерійний коефіцієнт кореляції 0,36 для Полісся та 0,65 для Лісостепу за критичного значення 0,32. Середня чутливість $є$ середньою для обох насаджень, тому що значення цього коефіцієнта перевищує 0,2 та менше 0,3. Чутливішими до варіацій умов довкілля є насадження в Лісостепу, що свідчить про менш сприятливі умови для росту дерев. Автокореляція $є$ високою для обох насаджень, що свідчить про значний вплив умов попереднього року на приріст поточного року (табл. 2).

\section{Статистична характеристика деревно-кільевих хронологій дуба звичайного в Поліссі} та Лісостепу, обчислених за програмою СОЕЕСНА

\begin{tabular}{lccccccc}
\hline $\begin{array}{l}\text { Природна } \\
\text { зона }\end{array}$ & $\begin{array}{c}\text { Кількість } \\
\text { річних } \\
\text { кілець }\end{array}$ & $\begin{array}{c}\text { Часовий } \\
\text { інтервал }\end{array}$ & $\mathrm{R}^{2}$ & $\begin{array}{c}\text { Середня величина } \\
\text { річного кільця (мм) }\end{array}$ & $\begin{array}{c}\text { Стандартне } \\
\text { відхилення }\end{array}$ & $\begin{array}{c}\text { Середня } \\
\text { чутливість }\end{array}$ & $\begin{array}{c}\text { Автокореляція } \\
\text { першого } \\
\text { порядку }\end{array}$ \\
\hline Полісся & 1164 & $1870-2013$ & 0,360 & 1,45 & 0,600 & 0,212 & 0,716 \\
\hline Лісостеп & 971 & $1914-2016$ & 0,665 & 2,39 & 1,241 & 0,293 & 0,624 \\
\hline
\end{tabular}

Примітка: $\mathrm{R}^{2}$ - міжсерійний коефіцієнт кореляції

Виявлено реперні роки, тобто роки максимального та мінімального приростів дуба звичайного для Полісся та Лісостепу (рис. 2, табл. 3).

Локальні хронології Полісся та Лісостепу $\epsilon$ основою для аналізу реперних років. Для дуба звичайного було визначено вісім реперних років з од- наковою тенденцією зростання (один рік 3 позитивними та сім 3 негативними тенденціями) для обох насаджень. Для Полісся виявлено 11 реперних років максимального приросту та 14 років мінімального; для Лісостепу, відповідно, виявлено 8 та 22 років за досліджувані періоди. 


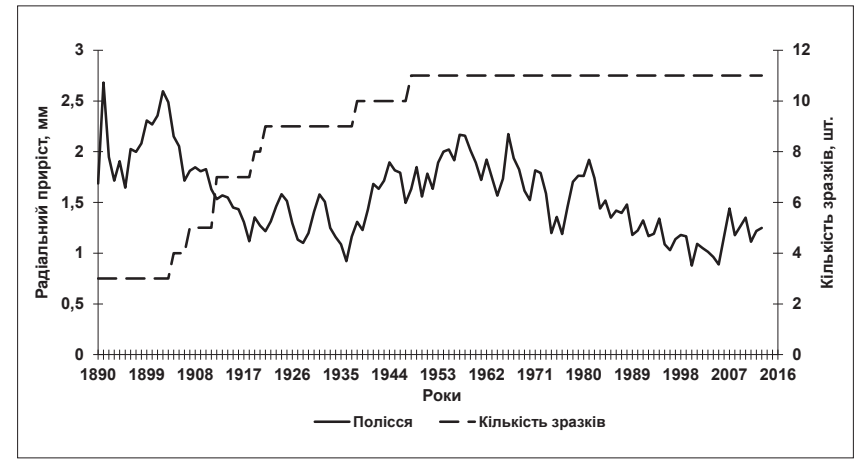

а) Полісся

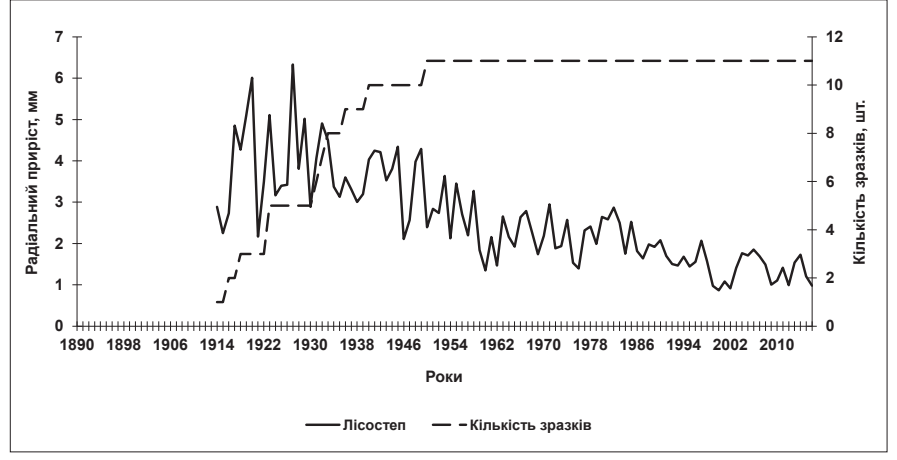

б) Лісостеп

Рис. 2. Динаміка радіального приросту дуба звичайного в Поліссі та Лісостепу

Таблиия 3

Реперні роки у деревно-кільцевих хронологіях Quercur robur L. у Поліссі та Лісостепу

\begin{tabular}{|c|c|c|c|c|c|c|c|c|c|c|c|c|c|c|}
\hline Рік & П. & Л. & Рік & П. & Л. & Рік & П. & Л. & Рік & П. & Л. & Рік & П. & Л. \\
\hline 1890 & & & 1917 & & & 1944 & + & & 1971 & + & + & 1998 & & \\
\hline 1891 & + & & 1918 & - & - & 1945 & & & 1972 & & & 1999 & & \\
\hline 1892 & & & 1919 & & & 1946 & & & 1973 & & & 2000 & - & - \\
\hline 1893 & & & 1920 & & & 1947 & & & 1974 & & & 2001 & & \\
\hline 1894 & & & 1921 & & & 1948 & & & 1975 & & & 2002 & & \\
\hline 1895 & - & & 1922 & - & - & 1949 & & & 1976 & - & - & 2003 & & \\
\hline 1896 & & & 1923 & & & 1950 & - & - & 1977 & & & 2004 & & \\
\hline 1897 & & & 1924 & + & & 1951 & & & 1978 & & + & 2005 & - & - \\
\hline 1898 & & & 1925 & & & 1952 & & & 1979 & & - & 2006 & & + \\
\hline 1899 & & & 1926 & & & 1953 & & & 1980 & & & 2007 & + & \\
\hline 1900 & & & 1927 & & & 1954 & & - & 1981 & + & & 2008 & & \\
\hline 1901 & & & 1928 & & & 1955 & & & 1982 & & + & 2009 & & \\
\hline 1902 & + & & 1929 & - & & 1956 & & & 1983 & & & 2010 & & \\
\hline 1903 & & & 1930 & & - & 1957 & + & - & 1984 & & - & 2011 & & \\
\hline 1904 & & & 1931 & + & & 1958 & & & 1985 & & + & 2012 & & \\
\hline 1905 & & & 1932 & & & 1959 & & & 1986 & & & 2013 & & - \\
\hline 1906 & - & & 1933 & & & 1960 & & - & 1987 & + & + & 2014 & & \\
\hline 1907 & & & 1934 & & & 1961 & & & 1988 & & - & 2015 & & + \\
\hline 1908 & & & 1935 & & - & 1962 & & & 1989 & & & 2016 & & \\
\hline 1909 & & & 1936 & - & & 1963 & & & 1990 & & & & & \\
\hline 1910 & & & 1937 & & & 1964 & & & 1991 & & & & & \\
\hline 1911 & & & 1938 & & - & 1965 & & & 1992 & - & - & & & \\
\hline 1912 & & & 1939 & & & 1966 & + & & 1993 & - & - & & & \\
\hline 1913 & & & 1940 & & & 1967 & & + & 1994 & & & & & \\
\hline 1914 & & & 1941 & & & 1968 & & & 1995 & & - & & & \\
\hline 1915 & & & 1942 & & & 1969 & & - & 1996 & - & & & & \\
\hline 1916 & & & 1943 & & - & 1970 & & & 1997 & & + & & & \\
\hline
\end{tabular}

Примітка: П - Полісся, Л - Лісостеп; реперні роки (+ позитивні реперні роки, - негативні реперні роки); загальні реперні роки мінімального приросту для Полісся та Лісостепу марковані сірим кольором, реперні роки максимального приросту - темно-сірим кольором. 
Позитивні реперні роки пов'язані 3 високою сумою опадів за рік, а також упродовж осінньозимового періоду i, насамперед, у травні-липні, коли їхня кількість перевищує середнє значення.

Для негативних реперних років характерні низька кількість річних опадів, які є нижчими, ніж багаторічні, а також посухи влітку, холодні або надто теплі зими. Водночас позитивний тренд відображає достатній запас води в місцях зростання дерев, особливо влітку. Зокрема, 1976 р. наведено як приклад негативного реперного року. У Поліссі сума опадів за квітень-червень цього року була нижчою на $29 \%$, порівняно зі середніми значеннями (123 мм випало у квітні-червні у 1976 р., середнє багаторічне значення за цей період становило 174 мм). Температури впродовж цього періоду перевищили середні значення майже на $12 \%$ (для 1976 р. вони становили $15,1^{\circ} \mathrm{C}$, а багаторічні значення $-13,3^{\circ} \mathrm{C}$ ). До того ж у Поліссі була надзвичайно холодна зима у 1976 р., коли середні зимові температури становили $-5,9^{\circ} \mathrm{C}$ (за норми $-3,8^{\circ} \mathrm{C}$ ), тобто температури були нижчими більше ніж у 1,5 раза. До того ж посушливим був попередній 1975 р., який ослабив насадження. Опадів випало на $15 \%$ менше від норми (відповідні дані - 518, 2 мм та 607,4 мм). Температура була вищою від норми цього року на $16 \%$ (середньорічна температура за 1975 р. становила $+8,5^{\circ} \mathrm{C}$, а норма $-+7,3^{\circ} \mathrm{C}$ ).

Тобто, незважаючи на те, що загалом температури за рік були вищими у 1975 р. порівняно з 1976 р., а опадів випало менше як у Поліссі, так і в Лісостепу, мінімальні прирости спостерігалися у 1976 р., тому що весняний та ранньолітній періоди виявилися посушливими в період активного формування річних кілець. До того ж надзвичайно низькі температури взимку негативно вплинули на приріст.

Упродовж позитивних реперних років спостерігалося сприятливе співвідношення тепла та вологи. Зазвичай кількість опадів протягом такого року була вищою від норми. Наприклад, у Поліссі, у 2007 р. випало за рік 764 мм, водночас норма становила 607 мм, що майже на 26\% вище від норми. Для Лісостепу позитивним реперним роком був 2014-й, протягом квітня-серпня якого випало 318,46 мм опадів за норми 260,70 мм, що на $22 \%$ вище від норми.

Загальні реперні роки мінімального приросту для насаджень обох природних зон відзначено у 1918, 1922, 1950, 1976 та 2005 рр., а максимального приросту - 1971 та 1987 роках.

Подібні результати отримано під час дослідження дубових насаджень в умовах Центрального Полісся, де приріст обмежували низькі та високі температури впродовж зими та ранньої весни, а також посухи вегетаційного періоду (Andrushchenko \&, Koval, 2014).

У Поліссі у перший період (1960-1988рр.) радіальний приріст дуба звичайного обмежували температури травня та червня. Також негативно впливали температури вересня, протягом якого закінчується процес формування річних кілець. Упродовж другого періоду (1989-2013 рр.) серпневі, вересневі та грудневі температури попереднього року позитивно вплинули на приріст поточного року (рис. 3).

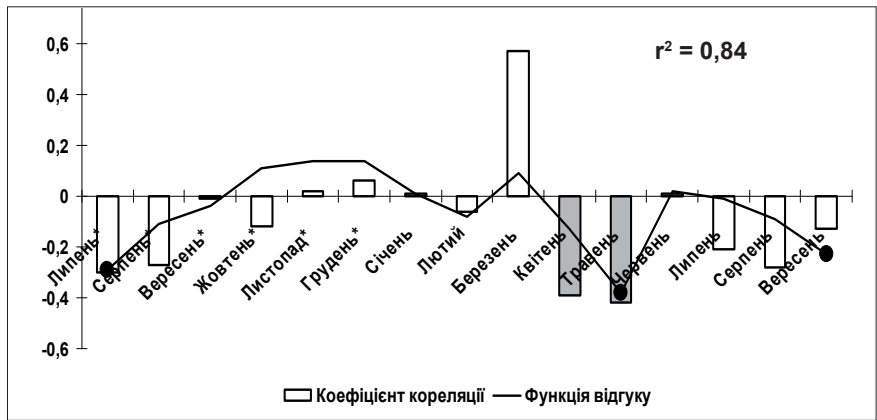

a) Температура. 1960-1988 pp.

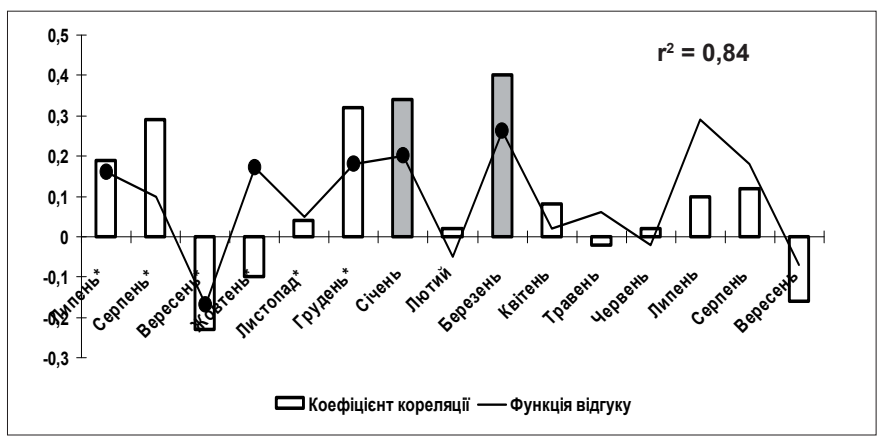

c) Опади. 1960-1988 pp.

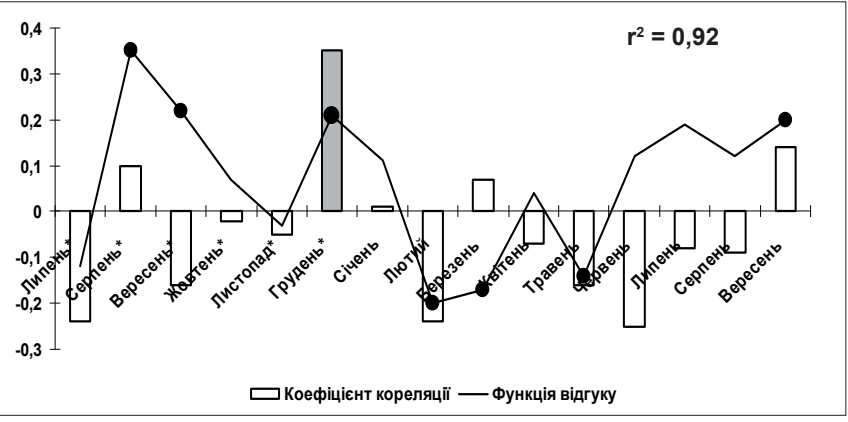

b) Температура. 1989-2013 pp.

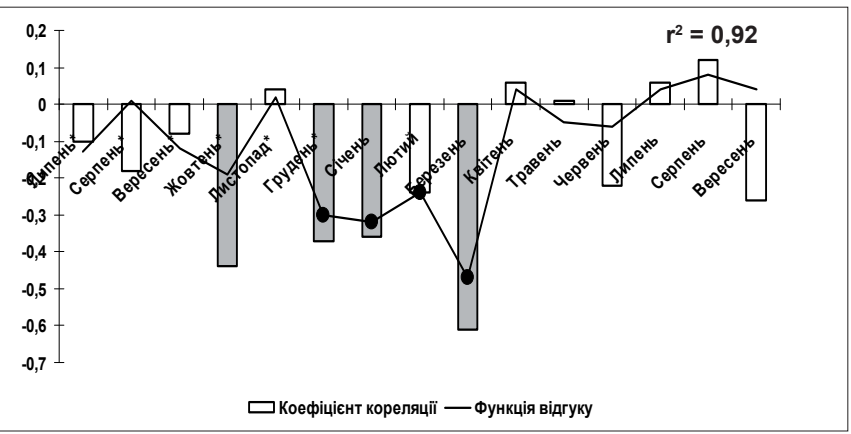

d) Опади. 1989-2013 pp.

Рис. 3. Кореляційний аналіз та аналіз функції відгуку для середньомісячних температур та індексної деревнокільцевої хронології RESIDUAL для шарів річної деревини дуба звичайного в Поліссі. Значущі кореляції на рівні 0,05 позначено сірими стовпчиками, а значущі зв'язки між температурами та радіальним приростом - чорними колами $(\mathrm{p} \leq 0.05)$. Місяці попереднього року позначено зірочками. 
У першому періоді опади позитивно впливали на радіальний приріст у липні та упродовж майже всієї зими та ранньої весни. У другому періоді опади обмежували приріст як у жовтні попереднього року, коли дерева входили у стан зимового спокою та відбувалося вологонагромадження в грунті, так i упродовж зими та ранньої весни (див. рис. 3).

У Лісостепу позитивний вплив температур вегетаційного періоду попереднього року, характерний для першого періоду, зник у другому періоді. По- тепління у лютому та березні негативно вплинуло на формування річних кілець. Червневі температури обмежували приріст як у першому, так і у другому періодах. У другому періоді потепління у квітні позитивно вплинуло на приріст. У першому періоді виявлено загалом позитивний вплив опадів на приріст протягом вегетаційного періоду, за винятком червня. У другому періоді в цей час температури обмежували приріст і лише в серпні-вересні відмічено позитивні кореляції (рис. 4).

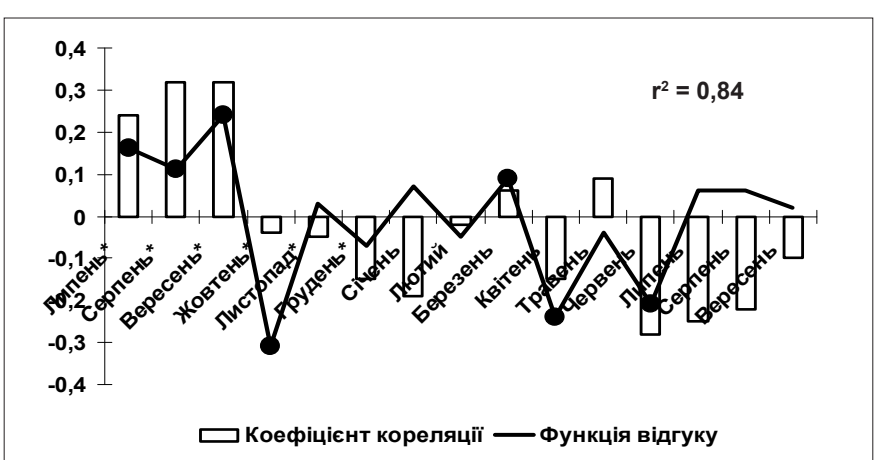

а) Температура. 1960-1988 pp.

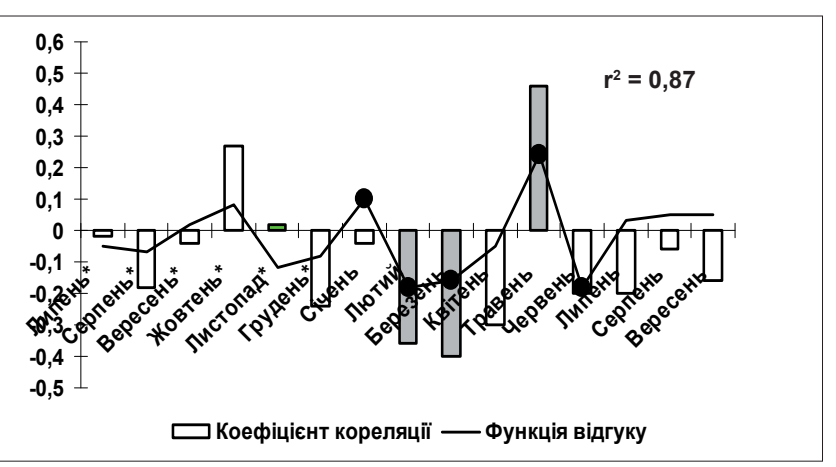

b) Температура. 1989-2013 pp.

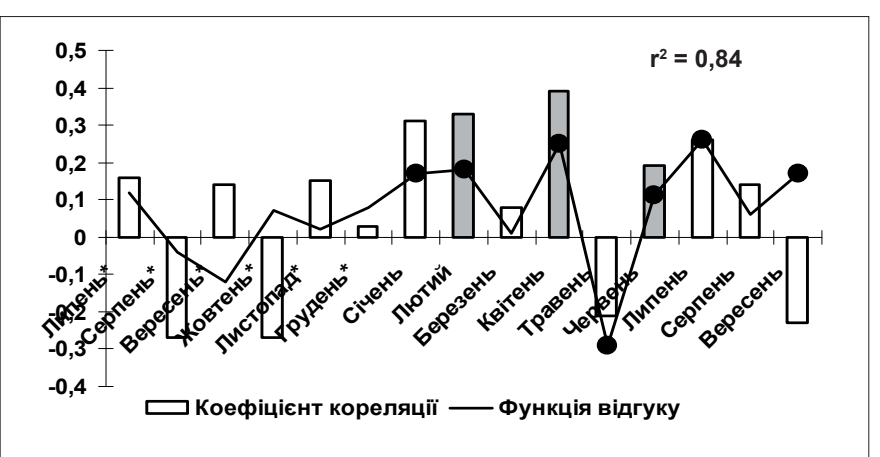

c) Опади. $1960-1988$ pp.

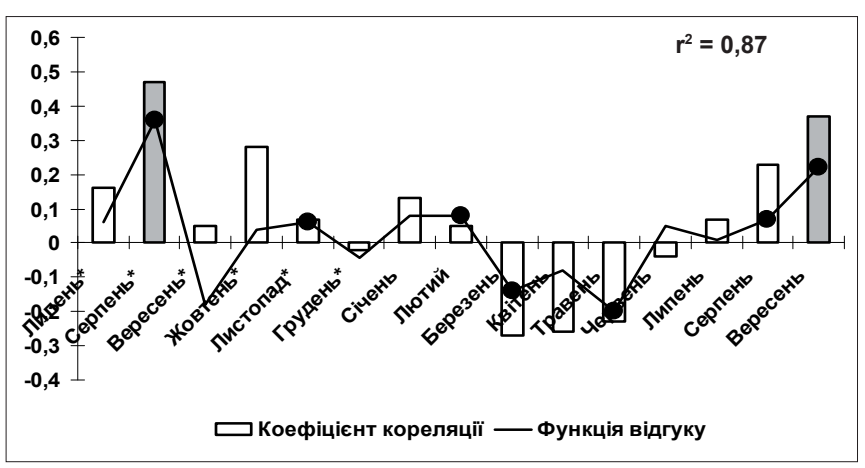

d) Опади. 1989-2013 pp.

Рис. 4. Кореляційний аналіз та аналіз функції відгуку для середньомісячних температур та індексної деревнокільцевої хронології RESIDUAL для шарів річної деревини дуба звичайного в Лісостепу. Значущі кореляції на рівні

0,05 позначено сірими стовпчиками, а значущі зв'язки між температурами та радіальним приростом - чорними колами $(\mathrm{p} \leq 0.05)$. Місяці попереднього року позначено зірочками

Отже, для обох природних зон у першому періоді відзначено істотний позитивний вплив температур взимку та ранньою весною (з грудня попереднього року по березень поточного року в Поліссі та $з$ січня по квітень у Лісостепу). Однак у другому періоді ситуація змінюється на протилежну - упродовж холодного періоду температури обмежують приріст. Вірогідно, відбувається, по-перше, порушення зимового спокою дерев внаслідок підвищених температур та, по-друге, внаслідок порушення стійкого снігового покриву зменшується вологозапас у грунті навесні, що також негативно впливає на радіальний приріст дуба. Значущий позитивний вплив температур виявлено лише для Лісостепу для серпня-вересня, що може свідчити про пізніше закінчення сезонного процесу ксилогенезу. У першому періоді в Лісостепу, на відміну від Полісся, виявлено значущий позитивний вплив тем- ператур декількох місяців вегетаційного періоду (липень-вересень) попереднього року на радіальний приріст дуба. У Поліссі ж виявлено негативний вплив липневих температур попереднього року на формування річних кілець. У Лісостепу негативно вплинули на приріст жовтневі температури, тобто їх підвищення у цей період могло негативно вплинути на вологонагромадження у грунті і як наслідок - зменшення приросту в наступному році. Березневі температури, які є важливими для початку процесу ксилогенезу, позитивно та достовірно впливали на радіальний приріст дуба у Лісостепу. Негативний вплив температур квітня-вересня виявлено для обох насаджень, але значущі негативні впливи розраховано для Полісся в квітні-травні (інтенсивний приріст) та вересні (завершення вегетаційного сезону) та для Лісостепу в квітні та червні (див. рис. 3, 4). 
У другому періоді в Поліссі виявлено значущий позитивний вплив температур серпня, вересня та грудня попереднього року на приріст, на відміну від Лісостепу. Негативний вплив температур лютого і березня на приріст спостерігався в обох насадженнях. Порівняно з першим періодом, ці зв'язки посилилися, а для Лісостепу у першому періоді навіть спостерігався позитивний вплив березневих температур на приріст. У Поліссі травневі температури позитивно впливали на приріст, а в Лісостепу навпаки - негативно. Для Полісся позитивний вплив температур на приріст $є$ характерним для вересня: підвищення температур у цьому місяці могло продовжити процес ксилогенезу, тобто процес формування річних кілець. Для обох насаджень загальним $є$ те, що у другому періоді, порівняно 3 першим, значно посилився негативний вплив температур на приріст наприкінці зими - на початку весни.

Під час порівняння впливу опадів на радіальний приріст дуба у Поліссі та Лісостепу у першому періоді виявлено, що для обох насаджень характерний позитивний вплив опадів на приріст у зимово-весняний період. Однак для Полісся він починається раніше - у грудні і закінчується в березні, тоді як для Лісостепу цей позитивний вплив починається у грудні і завершується у квітні. У Лісостепу приріст обмежують квітневі температури. Для Полісся характерний позитивний вплив для місяців попереднього року та місяців холодного періоду (з грудня попереднього року по березень поточного року, виняток - лютий) та ранньої весни (березень). Для Лісостепу характерним є позитивний вплив опадів з січня по квітень, за винятком березня, для якого значущих зв'язків не виявлено. Для літньо-ранньоосіннього періоду характерний позитивний вплив опадів тільки для Лісостепу.

Упродовж другого періоду як для Полісся, так i для Лісостепу загальним $\epsilon$ те, що вплив опадів на приріст протягом зимово-весняного періоду для Полісся та Лісостепу став негативним, на відміну від першого періоду, коли спостерігався позитивний вплив опадів на приріст. Для Полісся цей період триває $з$ листопада по квітень та для Лісостепу -3 березня по травень. Упродовж вегетаційного періоду опади значуще обмежували приріст лише у серпні-вересні у Лісостепу.

Отже, упродовж другого періоду опади істотно втратили позитивний вплив на приріст у насадженнях як Полісся, так і Лісостепу.

Дендрокліматологічний аналіз Taxus baccata L. у Польщі вказав на негативний вплив температури взимку та ранньою весною як основний чинник, що обмежує приріст. Літня посуха була додатковим чинником, який обмежив формування річних кілець. Для дерев Sorbus torminalis L. прохолодні та вологі літні місяці у вегетаційний період сприяють формуванню широких річних кілець (Cedro \& Cedro, 2015).

У південних районах регіону Балтійського моря радіальний приріст Quercus robur найбільш сильно та значуще пов'язаний з червневими та літніми опадами для 1943-1972 та 1973-2002 років. Червне- ві опади в рік формування річного кільця були найбільш послідовно та позитивно пов'язані 3 шириною річного кільця дуба. Найбільшу зміну реакції радіального приросту дуба виявлено до температур лютого упродовж двох періодів - 1943-2002 рр. та 1973-2002 років (Harvey et al., 2020).

Деревно-кільцеві хронології Quercus robur країн Східної Свропи показали, що протягом 19431972 pp. формування річних кілець було позитивно пов'язане із середньою температурою лютого, однак ці взаємозв'язки знижуються за останні десятиліття. Радіальний приріст дуба залежить насамперед від кількості опадів. Висока щорічна кількість опадів, зокрема рясний дощ навесні та влітку, призводить до появи широких кілець дерева. Опади у вигляді дощу та снігу взимку також сприяють росту дерев, підвищуючи рівень грунтових вод та покращуючи водопостачання в середовищі існування впродовж наступної весни. Засухи навесні і влітку у поєднанні з високою температурою повітря призводять до формування вузьких кілець. Висока чутливість дуба до тривалих дій посухи, що безпосередньо впливають на ріст дерев, може використовуватися як ознака раннього попередження необхідності прийняття належних планів та стратегій управління лісами, які мають вирішальне значення для підвищення їхньої стійкості до майбутніх екстремальних подій (Roibu et al., 2020).

Радіальний приріст дуба звичайного з південносхідної України має значущі зв'язки з весняними та літніми опадами, а також 3 температурами квітня, червня та липня, $з$ пізньозимовими та ранньовесняними температурами (Netsvetov et al., 2017).

За результатами кореляційного аналізу виявлено негативний вплив опадів на радіальний приріст дуба у липні-серпні 1951-1987 років. У наступні 1988-2011 рр. зимові опади позитивно вплинули на формування шарів річної деревини дуба. Для 1988-2011 рр. значущих зв'язків індексів радіального приросту дуба з опадами за вегетаційний період не виявлено (Коваль \& Kostyashkin, 2015).

Загальний кліматичний сигнал у кільцях дуба в Центральній Європі вказав на загальну позитивну реакцію приросту на опади навесні та влітку (березень і червень) та негативну реакцію на температуру навесні і влітку (квітень та червень), а також на загальну позитивну реакцію на опади, особливо навесні (травень), та негативну - на високі літні температури (особливо в серпні), з вираженим градієнтом з півночі на південь. Теплий попередній грудень і теплий поточний вересень позитивно впливають на ріст дерев, особливо у південно-західній частині досліджуваної території (Cufar et al., 2014).

Аналіз функцій відгуку приросту на кліматичні чинники показали, що радіальний приріст дуба звичайного в заплавних умовах найбільшою мірою пов'язаний 3 температурами на початку вегетаційного сезону. Для дерев, що ростуть в мезотрофних умовах, основний вплив на приріст виявляє режим опадів (Knysh \& Ermokhin, 2019).

Висновки. У Поліссі та Лісостепу відбулося підвищення температури у другому періоді (1988- 
2013 рр.), порівняно $з$ першим (1960-1988 рр.), на 17-19\%. Найшвидшими темпами підвищувалися зимові температури (на $34-41 \%$ ) та ранновесняні (березневі температури) - майже вчетверо в Поліссі та майже втричі - в Лісостепу. Тенденції опадів подібні для обох природних зон - відбулося підвищення річної кількості опадів, але впродовж вегетаційного періоду їх випало менше у Поліссі у квітнічервні на $11 \%$, а в Лісостепу упродовж липня-серпня та зимового періоду - на 10\% менше.

Виявлено реперні роки максимального (1891, $1902,1924,1931,1957,1971,1987)$ та мінімального $(1895,1906,1918,1922,1929,1936,1950,1976$, $1992,2000,2005)$ радіального приросту дуба звичайного для Полісся, а також позитивні $(1971,1978$, 1987) та негативні $(1918,1922,1929,1936,1950$, 1976, 1992, 2000, 2005) реперні роки для Лісостепу. Негативні реперні роки характеризуються дефіцитом опадів, посухами вегетаційного періоду, холодними або занадто теплими зимовими та ранньовесняними періодами, а позитивні - сприятливим для росту дерев співвідношенням тепла і вологи.

Для першого періоду (1960-1988рр.) виявлено позитивний вплив зимових та ранньовесняних температур на радіальний приріст дуба у Поліссі і в Лісостепу У другому періоді (1989-2013 рр.) відбувся протилежний сценарій - значне підвищення зимових та ранньовесняних температур призвело до зменшення радіального приросту. У другому періоді дубові насадження в Поліссі більше потерпали від теплих зим, ніж насадження Лісостепу. Негативний вплив посух вегетаційного періоду на приріст посилився у другому періоді для обох насаджень.

Упродовж другого періоду опади істотно втратили позитивний вплив на приріст у насадженнях як Полісся, так і Лісостепу.

Отже, $є$ підстава вважати підтвердженою гіпотезу щодо посилення чутливості реакції радіального приросту дуба звичайного до змін клімату в Поліссі та Лісостепу.

\section{References}

Andrushchenko, R.O., \& Koval, I. M. (2014). Radial growth of oak (Quercus robur L. ) phenoforms in places of winter moth (Operophera brumata L.) mass reproduction in Cenral Woodland Forests. Scientific reports National University of Life and Environmental Sciences of Ukraine, 5. Retrieved from http://nbuv.gov.ua/UJRN/Nd_2014_5_21 (in Ukrainian).

Cedro, A. (2007) Tree-ring chronologies of downy oak (Quercus pubescens), pedunculate oak ( $Q$. robur) and sessile oak (Q. petraea) in the Bielinek Nature Reserve: comparison of the climatic determinants of tree-ring width. Geochronometria, 26, 39-45. https:// doi.org/10.2478/v10003-007-0005-2.

Cedro, A., \& Cedro, B. (2015). Growth-climate relationships at yew and wild service trees on the eastern edge of their range in Europe. Forest Systems,
24 (3). Retrieved from https://dialnet.unirioja.es/ servlet/articulo?codigo $=6240057$.

Cufar, K., Grabner, M., Morgós, Martínez del Castillo E., Merela M, \& de Luis M. (2014). Common climatic signals affecting oak tree-ring growth in SE Central Europe. Trees, 28, 1267-1277. https://doi. org/10.1007/s00468-013-0972-z.

Didukh, Y. (2009). Ecological aspects of the global climate changes: reasons, consequences and actions. Proceedings of the Forestry Academy of Sciences of Ukraine, 2, 34-44 (in Ukrainian). Retrieved from http://nbuv.gov.ua/UJRN/vnanu_2009_2_12 (in Ukrainian).

Ducousso, A., \& Bordacs, S. (2004). Technical Guidelines for genetic conservation and use for pedunculate and sessile oaks (Quercus robur and $Q$. petraea). International Plant Genetic Resources Institute, Rome, Italy. Retrieved from https://www. bioversityinternational.org/fileadmin/user_upload/ online_library/publications/pdfs/1038.pdf.

Fischer, R., Beck, W., Calatayud, V., Cools, N., De Vos B., Dobbertin M., \& Stofer, S. (2011). The condition of forests in Europe. 2011 executive report. Hamburg: Institute for World Forestry.

Fritts, H., C. (1976). Tree rings and climate. London: Acad. press.

Geographical encyclopedia of Ukraine: in 3 volumes (1990). Editor.: O. M. Marynych (ed.) and others. Kyiv: Ukrainian Soviet Encyclopedia named after M.P. Bazhana (in Ukrainian).

Grissino-Mayer, H.D. (2001). Evaluating accuracy: a manual and tutorial for the computer program COFECHA. Tree-ring research, 57 (2), 205-221. Retrieved from https://repository.arizona.edu/ bitstream/handle/10150/251654/trr-57-02-205-221. pdf? sequence $=1$.

Harvey, J. E., Smiljanić, M., Scharnweber, T., Buras, A., Cedro, A., Cruz-García, R. ... Wilmking, M. (2020). Tree growth influenced by warming winter climate and summer moisture availability in northern temperate forests. Global Change Biology, 26, 25052518. https://doi.org/10.1111/gcb.14966.

Holmes, R.J. (1994) Dendrochronology Program Library-Users Manual. University of Arizona: Tucson, AZ, USA.

Kaennel, M., \& Schweingruber, F.H. (1995). Multilingual glossary of dendrochronology. Terms and definitions in English, German, French, Spanish, Italian, Portuguese and Russian. Swiss Federal Institute for Forest, Snow and Landscape Research: Berne, Haupt, 467.

Kätzel, R., \& Höppner, K. (2011). Adaptation strategies in forest management under the conditions of climate change in Brandenburg. Folia Forestalia Polonica, series A, 53 (1), 43-51. Retrieved from https://pdfs.semanticscholar.org/b8ad/e9ba16eeb 600a1e1cdb5c67c7c86c7296dd6.pdf.

Knysh, N.V., \& Ermokhin, M.V. (2019). Influence of climatic factors on the growth of pedunculate oak (Quercus robur L.) in the southern regions of Belarus. 
Proceedings of the National Academy of Sciences of Belarus. Series of biological sciences Volume, 64 (2), 156-168 https://doi.org/10.29235/1029-8940-201964-2-169-179 (in Russian).

Koval, I.M., \& Kostyashkin, D.C. (2015). Influence of Climate and Recreation on Formation of Layers of Annual Wood of Early and Late Forms Quercus robur L. in Kharkiv Greenbelt. Scientific Bulletin of Ukrainian National Forestry University, 25 (6), 52-58 Retrieved from https://nv.nltu.edu.ua/ Archive/2015/25_6/11.pdf (in Ukrainian).

Melekhov, I.S. (1979). Significance of the structure of annual layers and its dynamics in forestry and dendroclimatology. Forest Journal, 4, 6-14 (in Russian).

Netsvetov, M., Sergeyev, M., Nikulina, V., Korniyenko, V., \& Prokopuk, Yu. (2017). The climate to growth relationships of pedunculate oak in steppe. Dendrochronologia, 44, 31-38. https://doi. org/10.1016/j.dendro.2017.03.004.

Orlowsky, B., \& Seneviratne, S. (2012) Global changes in extreme events: regional and seasonal dimension. Climatic Change, 110, 669-696. https:// doi.org/10.1007/s10584-011-0122-9.

Roibu, C., Sfeclă, V., Mursa, A., Ionita, M., Nagavciuc, V., Chiriloaei, F., Les, I., \& Popa, I. (2020). The Climatic Response of Tree Ring Width Components of Ash (Fraxinus excelsior L.) and Common Oak (Quercus robur L.) from Eastern Europe. Forests, 11, 19. Retrieved from https://www.mdpi.com/19994907/11/5/600/htm.

Speer, J. H. (2010). Fundamentals of tree-ring research. The University of Arizona Press: Tucson.

Williams, J.T. (1992). International aspect of biodiversify. Forest. Choron, 4, 454-458.

Cook, E.R., \& Kairiukstis, L. (1990). Methods of Dendrochronology - Applications in the Environmental Sciences. Dordrecht, Nether-lands: Kluwer Academic Publishers and International Institute for Applied Systems Analysis.

\section{Реакция радиального прироста Quercus robur L. на изменения климата в Полесье и Лесостепи}

\author{
И.М. Коваль ${ }^{1}$
}

Исследованы спелые и перестойные дубовые насаждения в Полесье и Лесостепи, которые растут в условиях свежего сугруда и свежего груда.

Коваль Ирина Михайловна - член-корреспондент Лесной академии наук Украины, кандидат сельскохозяйственных наук, старший научный сотрудник, ведуший сотрудник лаборатории экологии леса. Украинский научно-исследовательский институт лесного хозяйства и агролесомелиорации им Г.Н. Высоцкого, ул. Пушкинская, 86, Харьков, 61024, Украина. Тел.: +38-057-707-80-45, +38-063-28-21-995. E-mail: Koval_Iryna@, ukr.net ORCID: https://orcid.org/0000-0001-6328-1418
Установлены климатические факторы, влияющие на радиальный прирост Quercus robur L. в Полесье и Лесостепи, сравнены его реакции на изменения климата в обеих природных зонах.

Использованы стандартные дендрохронологические методы, которые позволили создать древесно-кольцевые хронологии дуба и оценить взаимосвязи между этими хронологиями и климатическими показателями.

Выявлены особенности реакции радиального прироста дуба к варьированию климата для 19601988 и $1989-2013$ годов.

Для обеих природных зон произошло повышение температуры во втором периоде, по сравнению с первым, на 17-19\%. Самыми быстрыми темпами повысились зимние температуры (на 34-41\%) и ранневесенние (мартовские температуры) - почти в четыре раза в Полесье и почти втрое - в Лесостепи. Выявлено, что тенденции осадков были похожими для обеих природных зон - произошло повышение годового количества осадков, но в течение вегетационного периода их выпало меньше в апреле-июне для Полесья - на $11 \%$, а для Лесостепи - в течение июля-августа и зимнего периода на $10 \%$ меньше.

Вычислены реперные годы максимального $(1891,1902,1924,1931,1957,1971,1987)$ и минимального $(1895,1906,1918,1922,1929,1936$, $1950,1976,1992,2000,2005)$ радиального прироста дуба обыкновенного для Полесья, а также положительные реперные года для Лесостепи (1971, $1978,1987)$ и негативные $(1918,1922,1929,1936$, 1950, 1976, 1992, 2000, 2005). Негативные реперные годы характеризуются дефицитом осадков, засухами вегетационного периода, холодными, или слишком теплыми зимами и аномальными температурами в ранневесенний период. Положительные реперные годы характеризуются благоприятным для роста деревьев соотношением тепла и влаги.

Для первого периода (1960-1988 гг.) выявлено положительное влияние зимних и весенних температур (с декабря предыдущего года по март текущего года) на радиальный прирост в Полесье и в Лесостепи (с января по апрель). Во втором периоде (1989-2013 гг.) значительное повышение зимних и ранневесенних температур привело к нарушению зимнего покоя деревьев и устойчивого снежного покрова, что стало причиной уменьшения влагозапасов в почве весной и вследствие этого произошло уменьшение радиального прироста. Насаждения в Полесье больше страдали от теплых зим, чем насаждения в Лесостепи во втором периоде. Негативное влияние засух вегетационного периода усилилось во втором периоде для обоих насаждений.

Во втором периоде как для Полесья, так и для Лесостепи характерно то, что влияние осадков на радиальный прирост дуба обыкновенного в течение периода с ноября прошлого года по апрель текущего для Полесья и для Лесостепи в течение марта-мая стало отрицательным, в отличие от первого 
периода, когда наблюдалось положительное влияние осадков на прирост.

Гипотеза об усилении чувствительности реакции радиального прироста дуба обыкновенного к изменениям климата в Полесье и Лесостепи подтверждена.

Ключевые слова: спелые и перестойные дубовые насаждения; климатические факторы; годичные кольца; положительные и негативные реперные годы; засухи; чувствительность дуба обыкновенного; корреляция, функция отклика.

\section{Radial growth of Quercus robur L. response to climate change in Polissya and Forest-Steppe}

\section{Koval ${ }^{1}$}

The objects of the study are the old oak stands in Polissya and Forest Steppe, growing in conditions of fresh sugrud and fresh grud. The aim of the study is to identify climatic factors affecting the oak (Quercus robur L.) radial growth in Polissya and the ForestSteppe and to compare its response to climate change in both natural areas.

Standard dendrochronological methods were used to generate the Quercus Robur L. tree-ring chronologies and to evaluate the relationship of the chronology with the meteorological records.

In comparison, the influence of climate on the European oak radial growth in 1960-1988 and 19892013 for both natural areas there was in temperature increase in the second period compared with the first

Iryna Koval - Corresponding Member of the Forestry Academy of Sciences of Ukraine, Ph.D. in Agricultural Sciences, senior researcher of Laboratory of Forest Ecology. Ukrainian Research Institute of Forestry and Forest Melioration after G. M. Vysotsky, 86 Pushkinska st., Kharkiv, 61024, Ukraine. Tel.: +38-057-707-8001, +38-063-28-21-995. E-mail: Koval_Iryna@ukr.net ORCID: https://orcid.org/0000-0001-6328-1418 by $17-19 \%$. In the second period in comparison with the first period temperatures increased most rapidly in Winter (by 34-41\%) and early spring almost by four times in Polissya iand Forest Steppe. Precipitation trends are similar for both natural zones - there was an increase in the annual amount of precipitation, but during the growing season they fell less in April-June of the Polissya zone - by $11 \%$, and for the forest-steppe zone - during July-August and the winter period - by $10 \%$ less.

The reference years of maximum (1891, 1902, $1924,1931,1957,1971,1987)$ and minimum (1895, 1906, 1918, 1922, 1929, 1936, 1950, 1976, 1992, 2000, 2005) radial growth of European oak for Polissya were revealed as well as positive signature years for and Forest-Steppe $(1971,1978,1987)$ and negative reference years $(1918,1922,1929,1936,1950,1976$, 1992, 2000, 2005). Negative reference years are characterized by a deficit of precipitation, droughts of the growing season, cold or too warm winter and early spring periods, and positive - favorable for tree growth ratio of temperature and moisture.

For the first period (1960-1988) the positive influence of winter and early spring temperatures on the radial growth of oak in Polissya and in the ForestSteppe was revealed. In the second period (1989-2013) the opposite scenario took place - a significant increase in winter and early spring temperatures growth. In the second period, oak stands in Polissya suffered more from warm winters than plantations in the ForestSteppe. The negative impact of vegetation droughts on growth increased in the second period for both plantations.

During the second period, precipitation significantly lost its positive effect on plantations growth both in the Polissya and Forest-Steppe.

The hypothesis of increasing the sensitivity of the European oak radial growth response on climate change in Polissya and Forest-Steppe has been confirmed.

Key words: old oak stands; climatic factors; annual rings; positive and negative reference years; droughts; sensitivity of European oak; correlation, response function. 